\title{
ARTICULATION OF THE PROBLEM OF CONTINUOUS PRIMARY SCHOOL TEACHER TRAINING TO WORK IN CONDITIONS OF INCLUSIVE EDUCATION IN THE MODERN PEDAGOGICAL DISKURS
}

\author{
Tamila Dzhaman \\ Candidate of Pedagogical Science (Ed.D.), Associate Professor, \\ Head of the Cabinet of Educational Work and Supplementary Education, \\ Rivne Regional Institute of Post-Graduate Pedagogical Education, Ukraine \\ e-mail: jaman-tv@ukr.net, orcid.org/0000-0003-2257-0875
}

\section{Summary}

In this article it was investigated the diskurson the one hand for understanding the modern state of problem's articulation of continuous primary school teacher training made on the basis of a review of normative documents and literature and inclusive education on the other hand. It was analyzed the evolution of views on (1) education of children with special educational needs and (2) approaches to understanding the teacher training to work in inclusive classes with projection on continuous professional development and conception of continuous education. The analysis of normative international and domestic documents, literature of continuous training of teachers and professional activity in terms of inclusive education, practical implementation in Ukraine, new demands to professional competence of modern teacher allowed us to show a sequence of contradictions. In conclusion, the sphere of inclusive education is developing rapidly in Ukraine in the last 10 years which resulted in development of the law and development in science researches in the field of inclusion. Only teacher who is integrated to the system of continuous training and is interested in self-development can integrate principles of inclusive education.

Keywords: humanization, educational environment, professional competences, education during the whole life, International context of the understanding continuous professional training and inclusion, domestic context.

DOI: https://doi.org/10.23856/4603

\section{Introduction}

The main ideas of the modern education are humanization and continuity. The concept of humanization of educational sphere is revealed the most eloquently through realization of the direction of inclusive education. With taking into account the conceptual and terminological paradigm of the word experience of reformation the educational sphere the role of high-quality training of specialists for implementation inclusive education to educational institutions of any level is being actualized. In particular the problem of continuous primary school teacher training to work in conditions of inclusive education is a particularly pressing issue now in Ukraine as the first institutionally mandatory bridgehead within which inclusive education is introduced. Besides that we see not only the problem of primary specialist training as especially urgent (in paradigm of university education), but also a problem of providing the system of continuity of primary school teacher training to work in conditions of inclusive education. That means firstly the sustainable systemic and systematic professional development of primary school pedagog, that is based on the principles of conscious attitude and motivation of teachers to self 
improvement within the profession, and also - intuitively regulated and controlled accountability for dynamics of professional development of workers of inclusive classes to adapt different directions and the content of inclusive education to the world innovations and also promoting the exploratory and creative nature of the professional activities of the employees of inclusive educational cultures.

The goal of this article: is to investigate the diskurs, on the one hand, for understanding the modern state of problem's articulation of continuous primary school teacher training made on the basis of a review of normative documents and literature and on the other hand inclusive education.

Our task: to trace the evolution of views on (1) education of children with special educational needs and (2) approaches to understanding the teacher training to work in inclusive classes with projection on continuous professional development and conception of continuous education.

\section{International context of the problem of teaching the children with special educational needs}

The international context of the question is very important for understanding that state of readiness that this ideas had when they came to Ukraine, who and how adapted them to realities of Ukraine and which development that received within Ukrainian pedagogical diskurs and within the diskurs of public administration measures in the field of inclusion.

So, on the tenth of December 1948 with the resolution 217 A (III) UN General Assembly approved and proclaimed "General human rights constitution". The declaration lays the foundation for the further development of ideas about general education for all people. This ideas were approved and developed in "Declaration of the human rights", that was adopted by the resolution 1386 (XIV) UN General Assembly from November $20^{\text {th }}$ year 1959 . It says, that "a child must be provided by the law and the other means with the special protection and it must be given the opportunities and favorable conditions, that will give it an opportunity to develop physically, mentally, morally, spiritually and socially in a healthy and normal way in the conditions of freedom and dignity". Also the fifth principle of declaration is a thesis "child who is physically or socially disabled or is mentally handicapped, there must be provided a special regime, education and care, that is necessary in view of its special state". The initiated ideas about accessibility of education and the necessity of adaptation the education system to the needs of completely all members of the process was continued and fixed by "Convention for the Suppression of Discrimination in Education" from December $14^{\text {th }} 1960$, that was adopted during the Geneva XXIII International Conference (1960) on public education. Conference has approved the principle of inadmissibility of discrimination and proclaimed the right of each person to education. The next stages on the way to inclusive education were indicated be the appearance of documents that were comprehensively aimed at meeting people needs with special educational needs from the most young age. In the "Declaration of the social progress and development UN", that was adopted by the Resolution of General Assembly UN from $11^{\text {th }}$ of December 1969, the important thesis about protection the rights and providing a welfare of $\langle\ldots\rangle$ disabled people; the provision of protection a people, that are suffering from physical and mental disabilities. And also the thesis about the goal of "...increasing the overall level of education during the whole life". In two years, on December $20^{\text {th }} 1971$, it was adopted the "Declaration about the rights of mentally retarded people", where states that "...mentally retarded person has right on a proper medical care and also a right on education...". "Declaration of the 
rights of personas with disabilities" from December $9^{\text {th }} 1975$ enshrines the right of people with disabilities on education and socialization (in general this two concepts are inseparable from each other). There is also one important document that amounted a format of social ties with the children with special educational needs, it's the "Convention about the children rights" (20th November 1989) in editions with changes approved by the resolution 50/155 UN General Assembly from 21th December 1995. Un State approves that “...incomplicable in mental or physical development child should lead a full and worthy life in conditions that provide her dignity, contribute to the feeling of self-confidence and facilitating its active participation in the life of society". Individual article attention is drawn to the purpose of providing an inferior child access to education services and professional training. The resolution 48/96 UN General Assembly from December 20 year 1993 "Standard rules for providing equal opportunities for disabled" states that UN State should encourage public dialogue to protect the rights of disabled. The deeper understanding of the ontological, educational and medical-rehab side of disabled life should be a part of educational programs for all children and should be included in training courses for teachers and professional of all stages.

The most important document on the way to inclusive education and at the same time the point of irreversibility of the process if "Salaman Declaration on Principles of Policy and Practical Activity in the Field of Education of Personas with Special Needs and Action Frames for Personas with Special Educational Needs", was approved by the United Nations Conference for education of personas with special educational needs: access and quality (Spain, the 7-10th June 1994). One of the principle thesis is categorical suggestion of the necessity and urgency of education provision for children, youth and adults with special educational needs in the borders of the conventional education system. Conventional schools with the inclusive orientation were defined as the most effective means of combating discriminatory treatment against people with the special educational needs, and also it were defined the benefits of teaching people with special educational needs in order to create a friendly atmosphere in a communities, to build inclusive society and providing for everyone.

On the wave of rhetoric of the Salamanca declaration there was approved a "Convention on the Rights of Persons with Disabilities" from $13^{\text {th }}$ of December 2006, that was ratify in Ukraine on $16^{\text {th }}$ of December 2009 and came into force on the third of June 2010. Article 24 of Convention was dedicated particulary to the questions of education. The convention was supplemented by a report from the European Commission "Children rights for all! Implementation of the Convention UN on the Rights of the Child for children with mental disabilities" year 2006. This report was intended to understand the children with developmental disabilities not only as children with physical health disabilities, but also as children with mental health disabilities, because the reports of many European Countries said about exclusion of children with intellectual disabilities against the background of the official movement towards the expansion of inclusion.

"The Council of Europe`s Strategy on the rights of the child" (2016-2021) reaffirmed its course towards inclusive education. With the requirements of the time and with all peculiarities of child's life in the information age, the Council of Europe initiates joint study on specific opportunities and risks for children with disabilities in the digital environment". The strategy of the Council of Europe is based on the recommendations of the Council of Europe for deinstitutionalization and life of children with the disabilities in a social life.

In a paradigm of clear direction of the Ukraine's movement towards European integration the main role plays European policy documents on compliance with European standards in the field of human rights. Especially the "Action plan for Ukraine for 2018-2021 years", that 
was offered by the Council Europe states that European Council will support the international informational campaign to promote respect for and understanding of vulnerable groups, as well as measures to combat discrimination and intimidation in the education system. IN a global understanding of dominants of inclusive education an important role plays "New guidelines for UNESCO's inclusion policy in the field of education" (2009).

Meanwhile the triad of regulatory acts of ratification of inclusive education as a fundamental approach to people with mental and physical disabilities consists from such international documents ( in addition to the previously named) as Salamanca declaration and the frameworks for action on the education of persons with special educational needs (1994); Convention on the rights of people with disabilities (2006); New guidelines of the UNESCO's inclusion policy in the field of education (2009).

During many years the policy on disabled people was changing: it has evolved from the conventional care for disable people in the corresponding institutions to that point where children with disabilities now have the opportunity to receive an education and people that became disable in the old age can receive rehabilitation care. Because of the education and the system of rehab measures disable people became more active in advocating the evolution of international and state policy for disabled people. After the second Word War the following concepts as integration and engaging disable people to the normal social life that reflected a progressive understanding of potential abilities of disable people. But even now under the definition of "inclusive education" in the countries that are the main providers of inclusive education, the definition itself is determined here and there with some semantic and corresponding procedural and implementation differences.

On the international level the idea of inclusion is considered mainly in avoiding the exclusion from the student environment those who have any special educational needs through the support of their needs. Such definition is the most close to that adopted by the "Law of Ukraine on Education” from 05.09.2017 № 2145-VIII, where inclusive education is a system of educational services that are guaranteed by the Country and are based on the principles of non-discrimination, taking into account human diversity, effective engagement to the educational process all of its members", and inclusive educational environments is defined as "the unity of conditions, approaches and methods of its realization for the coeducation teaching and development the students with taking into account their needs and abilities.

\section{Domestic context of the problem of children with the special needs education}

Analysis of treatment the approaches to children with the special needs education in Ukraine give us the opportunity to separate a few periods of it. A period that is related to the expansion the network of special educational institutions (1950-1991). A period that became the first stage of transition to inclusion in education in the conditions of independent Ukraine (1991-2010). From 2010 due to now is a period of implementation the inclusive classes to convenient schools and decreasing the number of special and boarding schools (Bilous, Constantyniuk, 2018). Historically the trends to invent inclusive education, with the understanding close to modern, can be noticeable on the territory of Ukraine yet from twenties-thirties years of the XX century (Kolupayeva, Taranchenko, 2016). In particular its about the opening of defectological faculty of Kiev pedagogical university, the dean of the University was at that time G. S. Kostiuk in 1921-1923 and in the years 1929-1933. Here was the training enabled for specialists to work with mentally retarded children and also with children who had hearing issues. On the $8^{\text {th }}$ of July 1931 the board of the People`s Commissariat of 
education approved the decision about inventing the general compulsory education of disable children of the age 8-15 years from the $1^{\text {st }}$ October 1933 (Gavrilov, 2009). The times of Soviet Ukraine are unfavorable for the inclusive education development. That's why we can not see the full historical movement in the direction of inclusive education in Ukraine as it is in the most European Countries. There was no law on special education in the Soviet Union because only $1,5 \%$ from the whole number of children, who had a need in a special psycho-pedagogical support were engaged to the educational system due to the end of 1990-1991 (for example there were $12 \%$ of children with peculiarities of psycho-physical development got the special education in the countries of the West Europe at the same time) (Gavrilov, 2009). As the result of this state of affairs in Ukraine at the time of gaining state independence there was almost no legal framework that could be identify the status of child with the special educational needs and could guarantee its right on education in the special educational institution or in conventional School.

The culmination of movement to inclusion became the order of the Ministry of Science and Education of Ukraine "About approval the conception of inclusive education development" (from 01. October 2010 № 912). It generalized all previous achievements of the legal framework for the implementation of inclusive education and defined the next directions. This order convincingly states the need for the special teacher training and retraining to work with children with special educational needs in the circumstances of inclusive education. In general for the modern stage of implementation the inclusive education in Ukraine are common: optimization of special educational institutions and cross-cutting implementation of inclusive approaches.

Improving the system of training and retraining of pedagogs that work in conditions of inclusive education also states from the Constitution and find its embodiment through the system on measurements of reformation the approaches to their primary state (within higher education institutions) and through the further teacher training.

\section{International context of understanding the continuous professional teacher training}

In the word the idea of continuous training the professional and its integration in the spectrum of social fields of person's in working age activity independently of geological characteristics or with the other words on a international level was happened when the words transitioned to the industrial economics. The additional factors that determine the demand for lifelong learning in XXI century are: wide access to the information, fast technological development, strengthening global interaction, changes in the field of education and also increasing the level of qualifications and skills for the beginning of professional activity (entry-level job) (Gaymer, 2006: 128). In the paradigm of continuous education interests of employer and employee are satisfied. Services of continuous education can be traditionally provided by governmental, non-governmental commerciall, and non-commercial organizations (Gaymer, 2006). If the term of continuous education carries more institutional character in the foreign perception, the term "education during the whole life" is a personally oriented notion of modern didactics. Likewise, if continuous education means mostly institutional events of qualification upgrading, which are clearly marked in time and localized, education during the whole life has broader semantics, involves many levels and subjects of educationally adaptive endeavors of a person who is learning. Education during the whole life by having clear personal orientation can involve a facilitator- tutor, however, the facilitator has to be qualified in the provision of an educational environment which gives a person opportunity to improve oneself and to achieve one's goals of education. 
Thus, on a global level, concepts of continuous professional development (education), education during the whole life, and inclusive education are basic indicators of humanization of the educational environment. Such conceptualization of the main educational trends is focused on formulated goal № 4 among 17 sustainable development goals as "to provide inclusive and quality education and to ensure general possibilities of education during the whole life" (UN, 2005; UN, n.d.). Despite a clear declarative-directive character of movement to inclusive education, the problem is still topical, for countries with the lower income particularly. For example, during the conference in Geneva in 2019 "Unlimited education: Education during the whole life and inclusive education" which was organized by UNICEF and UNESCO together with several international organizations, a claim was recognized and recorded in the accounting report that adequate access to pre-school, full secondary and higher education is still a problem to many countries, the for the most marginalized segments of the population, to children and young people with disabilities, particularly (UNECE, 2019). Additionally, in the UNESCO final report 2020 "Inclusion and education: all is everyone" the goal is formulated to ensure till 2030 that all boys and girls would receive free, equal, and quality primary and secondary education which will bring relevant and effective educational results.

\section{Continuous primary school teacher training to work in the context of inclusive education as a strategy educational task of Ukraine}

Inclusive education together with the problem of continuous specialists' training, teachers in particular, who are engaged in the implementation of inclusive education, are among the strategic educational issues of Ukraine as a country. Their proper satisfaction is the fulfillment of the social duty of a country to its citizens and is also a guarantor of the progressive development of the country, strengthening its positions in the world scene.

The document of the European agency in special needs and inclusive education (with the support of UNESCO) "The broadening of teachers' possibilities in promotion of inclusive education" (European Agency, 2015: 26) has the essential meaning for mutual integration of inclusive education and continuous teachers' training concepts. Paragraph 5.4 "Inclusive approaches to education" indicates the norms of individual professional teachers' development: teaching is shown as a learning activity; teachers are responsible for their education during their whole life. Teachers' university education is only the basis of continuous professional education and development.

Contemporary official directive and reporting documents of the world community are appealing to the issue of quality practicing teachers' training to work with inclusive classes. Thus, in "Inclusion and education: all is everyone" (2020) report a single paragraph "Programs of inclusion within teachers' training without a break from work have high demand in teachers" the problem of an acute need of teachers' training of pedagogic tactics, methods, techniques, and procedures of inclusive education is articulated (UNESCO, 2020).

Active development of inclusive education issues in Ukraine goes together with the fundamental reformation of the whole educational system and the implementation of New Ukrainian school (NUS). Directly, implementation of the reform started in 2017 and now involves the whole area of elementary school. The essence of NUS is perceived only in synergy with principles of inclusion as non-violent law of equal access to education for individuals of all categories regardless of physical, social, or other characteristics. Program documents of NUS allow inclusive education through the creation of conditions for studying pupils with disabilities together with children of their age, the implementation of individual programs of development for them. 
This engages not only the corrective and rehabilitative measures, providing necessary learning tools for children with special educational needs but also proper psychological and pedagogic support that mostly teacher initiates and controls. Moreover, teacher's and pupil's personality within NUS are simultaneously perceived through the paradigm of education during their whole life. The ability to learn during the whole life is marked in a special document MSE "New Ukrainian school: a conceptual framework for secondary school reform" (2016) as one of the ten basic competencies of NUS. It is described as "the ability of searching and assimilation of new knowledge, acquiring of new skills, organization of educational process (own and collective)". The algorithm of teacher's competency is always conceptualized through a personal effective government of resources and information flows (that is actual during digitalization and the domination of fake information); the ability to determine own educational goals and means of their fulfillment; creation of individual educational and professional trajectory; ability to assess critically and objectively the results of one's study, especially the ability to study during the whole life, i.e. systematically and to enrich the pedagogical worldview culture and expand professional competencies all the time. It is stated in the concept of New Ukrainian School that "the role of the teacher is important". To sum up, the primary feature is "the image of teacher who is creative and responsible and constantly develops himself/herself". Motivated and successful teacher is called to work constantly on the development of personality and professional skills and knowledge.

\section{Conclusions}

In conclusion, the sphere of inclusive education is developing rapidly in Ukraine in the last 10 years which resulted in development of the law and development in science researches in the field of inclusion. Only teacher who is integrated to the system of continuous training and is interested in self-development can integrate principles of inclusive education.

The analysis of normative international and domestic documents, literature of continuous training of teachers and professional activity in terms of inclusive education, practical implementation in Ukraine, new demands to professional competence of modern teacher allowed us to show a sequence of contradictions. There is certain contradictions in social-pedagogical sphere which is in difference between social order on implementation and releasing inclusive education in domestic pedagogical practice and lack of qualified teachers to embody inclusion. The other contradiction is fined in the theoretical field. There is a necessity of training teachers for schools and kindergartens in terms of inclusive education and there is lack of reasoning in science, technology and methodology of such trainings. On the practical methodological level there is a contradiction in terms of necessity of training teachers for implementing inclusive education and lack of programs and methodological support. The search for solutions of stated problems is a perspective direction of scientific researches.

\section{References}

Bilous O., Konstantyniuk S. (2018). Osvitaditei zosoblyvymypotrebamy: vid radianskoidiisnosti do suchasnykhtendentsii [Education of children with special needs: from the Soviet reality to modern trends]. URL: http://ua.inklusion-inklusija.com/inclusion_in_school_and_society [in Ukrainian].

Havrylov O. V. (2009). Osoblyvidity v zakladi i sotsialnomuseredovyshchi: navchalnyiposibnyk [Special children in the institution and the social environment: a textbook]. Kamianets-Podilskyi: Aksioma [in Ukrainian]. 
ZakonUkrainy "Pro osvitu» (2017). [Law of Ukraine "On Education"]. 05.09.2017 № 2145-VIII. URL: https://zakon.rada.gov.ua [in Ukrainian].

Kolupaieva A.A., Taranchenko O.M. (2016). Inkliuzyvnaosvita: vid osnov do praktyky [Inclusive education: from basics to practice]. Kyiv: TOV «ATOPOL» [in Ukrainian].

Nova ukrainskashkola: kontseptualnizasadyreformuvanniaserednoishkoly (2016) [The new Ukrainian school: conceptual principles of secondary school reform]. https://mon.gov.ual storage/app/media/nova-ukrainska-shkola-compressed.pdf (data zvernennia: 16.03.2018) [in Ukrainian].

Plan dii dlia Ukrainyna 2018-2021 rr. Komitetministriv RadyYevropy (2018) [Action Plan for Ukraine for 2018-2021. Committee of Ministers of the Council of Europe]. URL: https://rm.coe. int/ap-ukraine-2018-2021-ukr-local-lang-official-non-web/16809e4563 [in Ukrainian].

European Agency for Special Needs and Inclusive Education (2015).Empowering Teachers to Promote Inclusive Education.Literature Review. Odense, Denmark: European Agency for Special Needs and Inclusive Education. https://www.european-agency.org/sites/default/files/ Empowering\%20.pdf

Gaymer, D. M. (2006). Continuing Education and Lifelong Learning Trends. In M.M., Helms (Ed.) Encyclopedia of management (5th ed.), (pp.128-131).Farmington Hills, Michigan, USA: Thomson Gale Publishing.

Gaymer, D. M. (n. d.) Continuing education and lifelong learning trends. http://www. referenceforbusiness.com/management/Comp-De/Continuing-Education-andLifelong-Learning-Trends.html

UN. (n.d.). Sustainable Development Goals.The 17 Goals. https://sdgs.un.org/goals

UN. (2015). Resolution adopted by the General Assembly on 25 September 2015. Transforming our world: the 2030 agenda for sustainable development. http://www.un.org/ga/search/ view_doc.asp

UNECE (2019). Regional Forum on Sustainable Development for the UNECE Region (21-22 March 2019). https://unece.org/fileadmin/DAM/RCM_Website/SDG4_1.pdf

UNESCO (2020). Inclusion and education: All Means All. Global Education Monitoring Report. https://unesdoc.unesco.org/ark:/48223/pf0000373718/PDF 